\title{
Natural killer T (NKT) cells accelerate Shiga toxin type 2 (Stx2) pathology in mice
}

\author{
Fumiko Obata ${ }^{1,2 *}$, Priyanka B. Subrahmanyam ${ }^{1}$, Aimee E. Vozenilek ${ }^{1}$, \\ Lauren M. Hippler ${ }^{1}$, Tynae Jeffers ${ }^{1}$, Methinee Tongsuk ${ }^{1}$, Irina Tiper ${ }^{1}$, \\ Progyaparamita Saha ${ }^{1}$, Dakshina M. Jandhyala ${ }^{3}$, Glynis L. Kolling ${ }^{4}$, Olga Latinovic ${ }^{1,5}$ \\ and Tonya J. Webb ${ }^{1}$

\begin{abstract}
1 Department of Microbiology and Immunology, University of Maryland School of Medicine, Baltimore, MD, USA, ${ }^{2}$ Department of Molecular Pathology, University of Yamanashi Graduate School of Medicine, Chuo, Japan, ${ }^{3}$ Department of Molecular Biology and Microbiology, Tufts University, Boston, MA, USA, ${ }^{4}$ Division of Infectious Diseases and International Health, Department of Medicine, University of Virginia, Charlottesville, VA, USA, ${ }^{5}$ Institute of Human Virology, University of Maryland School of Medicine, Baltimore, MD, USA
\end{abstract}

OPEN ACCESS

Edited by:

Evangelos Giamarellos-Bourboulis, University of Athens, Greece

Reviewed by:

Malgorzata Anna

Mikaszewska-Sokolewicz,

The Medical University of Warsaw,

Poland

Eirini Christaki,

Agios Pavlos General Hospital, Greece

*Correspondence:

Fumiko Obata

Department of Molecular Pathology,

University of Yamanashi Graduate

School of Medicine, 1110 Shimokato,

Chuo, Yamanashi 409-3898, Japan

fumikoo@yamanashi.ac.jp

Specialty section:

This article was submitted to Infectious Diseases, a section of the

journal Frontiers in Microbiology

Received: 26 December 2014

Accepted: 16 March 2015

Published: 08 April 2015

Citation:

Obata F, Subrahmanyam $P B$ Vozenilek AE, Hippler $L M$, Jeffers $T$, Tongsuk M, Tiper I, Saha P, Jandhyala

$D M$, Kolling GL, Latinovic $O$ and Webb TJ (2015) Natural killer T (NKT)

cells accelerate Shiga toxin type 2 (Stx2) pathology in mice.

Front. Microbiol. 6:262.

doi: 10.3389/fmicb.2015.00262
Shiga toxin-producing Escherichia coli (STEC) is a leading cause of childhood renal disease Hemolytic Uremic Syndrome (HUS). The involvement of renal cytokines and chemokines is suspected to play a critical role in disease progression. In current article, we tested the hypothesis that NKT cells are involved in Stx2-induced pathology in vivo. To address this hypothesis we compared Stx2 toxicity in WT and CD1 knockout (KO) mice. In CD1KO mice, which lack natural killer T (NKT) cells, Stx2-induced pathologies such as weight loss, renal failure, and death were delayed. In WT mice, Stx2-specific selective increase in urinary albumin occurs in later time points, and this was also delayed in NKT cell deficient mice. NKT cell-associated cytokines such as IL-2, IL-4, IFN- $\gamma$, and IL-17 were detected in kidney lysates of Stx2-injected WT mice with the peak around $36 \mathrm{~h}$ after Stx2 injection. In CD1KO, there was a delay in the kinetics, and increases in these cytokines were observed $60 \mathrm{~h}$ post Stx2 injection. These data suggest that NKT cells accelerate Stx2-induced pathology in mouse kidneys. To determine the mechanism by which NKT cells promote Stx2-associated disease, in vitro studies were performed using murine renal cells. We found that murine glomerular endothelial cells and podocytes express functional CD1d molecules and can present exogenous antigen to NKT cells. Moreover, we observed the direct interaction between Stx2 and the receptor $\mathrm{Gb}_{3}$ on the surface of mouse renal cells by 3D STORM-TIRF which provides single molecule imaging. Collectively, these data suggest that $\mathrm{Stx} 2$ binds to $\mathrm{Gb}_{3}$ on renal cells and leads to aberrant CD1d-mediated NKT cell activation. Therefore, strategies targeting NKT cells could have a significant impact on Stx2-associated renal pathology in STEC disease.

Keywords: Shiga toxin, Escherichia coli, hemolytic uremic syndrome, natural killer $\mathrm{T}$ cell, cytokines, single molecule imaging, STORM-TIRF, mouse models

\section{Introduction}

Shiga toxin-producing Escherichia coli (STEC) causes renal disease, hemolytic uremic syndrome (HUS) (Karmali et al., 1985). HUS is a leading cause of renal failure in otherwise healthy 
children and Shiga toxin type 2 (Stx2) is often associated with severe symptoms of STEC infection (Lopez et al., 1989; Ostroff et al., 1989). In STEC patients, an increase in white blood cells (WBC) namely neutrophils and monocytes, is often associated with HUS (Gianantonio et al., 1973; Ryan et al., 1986; Martin et al., 1990; Robson et al., 1993; Su and Brandt, 1995; Perez et al., 1998; Dervenoulas et al., 2000; Ake et al., 2005; Fernandez et al., 2005; Ramos et al., 2007). Serum cytokines such as IL-6, IL-8, IL10 and TNF $\alpha$ are often found increased in STEC-HUS (Murata et al., 1998; Proulx et al., 1998; Shimizu et al., 2012; Valles et al., 2012). Similarly, in animal models, Shiga toxins-injected animals showed blood profiles such as an increase in neutrophils (Fernandez et al., 2006; Keepers et al., 2006; Sauter et al., 2008), IL-6 and TNF $\alpha$ (Sauter et al., 2008; Stearns-Kurosawa et al., 2010). In addition, several animal model studies have found a variety of cytokines and chemokines are produced in the kidney (Keepers et al., 2007; Roche et al., 2007; Sauter et al., 2008; Zanchi et al., 2008; Petruzziello-Pellegrini et al., 2012; StearnsKurosawa et al., 2013). The mechanism by which Shiga toxins rapidly induce many types of cytokines and chemokines, without a strong inflammatory factor like lipopolysaccharide, is not precisely understood.

NKT cells are a small population of immune cells in blood $(0.2-0.5 \%$ in mouse and $0.01-0.5 \%$ in human (Berzins et al., 2011), however they can serve as strong inducers of inflammation. NKT cells can rapidly secrete a large amount of cytokines, including Th1, Th2, and Th17 cytokines (Berzins et al., 2011), and these cytokines activate other immune cells (Matsuda et al., 2008). Unlike classic T cells, NKT cells recognize glycolipid antigens presented by CD1d molecules (Kawano et al., 1997). There are two types of NKT cells. Type I NKT cells express a semiinvariant TCR $\alpha$ chain $\mathrm{V} \alpha 24 \mathrm{~J} \alpha 18$ (human) or $\mathrm{V} \alpha 14 \mathrm{~J} \alpha 18$ (mouse) and can be activated with alpha-galactosylceramide ( $\alpha \mathrm{GC})$. Type II NKT cells express various TCR $\alpha$ chains and are restricted to CD1d, but cannot be activated with $\alpha$ GC. Mice lacking CD1 (CD1KO) are both type I and II NKT cell deficient. The involvement of CD1d-restricted NKT cells in STEC-mediated disease has never been described. We compared WT and CD1KO mice disease progression following Stx2 injection and observed that CD1KO mice had delayed Stx2-induced pathology.

Historically, it was controversial whether murine glomerular cells such as podocytes and endothelial cells interact with Stx2 for both reports that showed interaction (Morigi et al., 2006) and no interaction (Psotka et al., 2009) existed. On the other hand, human glomerular endothelial cells and podocytes are known to express $\mathrm{Gb}_{3}$ and are sensitive to Shiga toxins (Psotka et al., 2009). This has been a problem with the murine model in regards to the similarity to human pathology. We tested direct interaction of Stx2 with murine glomerular cell surface $\mathrm{Gb}_{3}$ in vitro using a sensitive imaging system, STochastic Optical Reconstruction Microscopy (STORM)-Total Internal Reflection Fluorescence microscope (TIRF) that has ability to image single molecules (Smyth and Shaw, 2008; Dempsey et al., 2011; Liesche et al., 2013). Also, using cellular assays, we tested the ability of Stx2-pretreated glomerular cells to activate NKT cells in vitro. Here for the first time we demonstrate that Stx2 induces CD1d-mediated activation of NKT cells via glomerular cells.

\section{Materials and Methods}

\section{Animals}

Male C57BL/6 (wild type, WT) mice weighing 22 to $24 \mathrm{~g}$ were purchased from Charles River Laboratories (Wilmington, MA, USA). Male CD1.1 $1^{-/}(\mathrm{CD} 1 \mathrm{KO})$ mice of the matched age were maintained in Webb lab (Carnaud et al., 1999; Park et al., 1999; Hua et al., 2011). Mice were housed in a $12 \mathrm{~h} / 12 \mathrm{~h}$ light and dark cycle and given access to food and water ad libitum. Mice were injected intraperitoneally $250 \mathrm{ng} / \mathrm{kg}$ Stx2 (two times the $50 \%$ lethal dose). At this dose of Stx $2,50 \%$ of WT mice die at approximately $72 \mathrm{~h}$, and $100 \%$ die by $96 \mathrm{~h}$ (Figure 1). This dose was chosen based on previous studies with our mouse model of HUS (Keepers et al., 2006). Weight and survival were monitored every $12 \mathrm{~h}$ using five mice per strain. In the different set of experiment, at selected time points after injection, three mice per time point were euthanized by $\mathrm{CO}_{2}$ inhalation and kidneys were removed. Kidneys collected at $0 \mathrm{~h}$ (prior to Stx 2 injection) were used for controls. Kidneys were processed for enzyme-linked immunosorbent assay (ELISA) as described below. Mouse blood was withdrawn into a $0.5 \mathrm{M}$ of sodium ethylenediaminetetraacetate $\left(\mathrm{Na}_{2} \mathrm{EDTA}\right)$ wetted needle and syringe from their heart at each time point to isolate plasma for blood urea nitrogen (BUN) assay. Blood from $0 \mathrm{~h}$ (prior to Stx2 injection) animals were used as controls. All animal procedures were performed in accordance with University of Maryland School of Medicine Animal Care and Use Committee policies (animal use protocol number 0811012).

\section{Cell Culture}

Vero cells were purchased from American Type Culture Collection (ATCC, Manassas, VA) and maintained in RPMI1640 media (Life Technologies, Grand Island, NY) supplemented with $10 \%$ fetal bovine serum (HyClone/ThermoFisher Scientific, Waltham, MA), $2 \mathrm{mM}$ L-glutamine (Cellgro/Mediatech, Manassas, VA) and $100 \mathrm{U} / \mathrm{ml}$ penicillin and $100 \mu \mathrm{g} / \mathrm{ml}$ streptomycin (Life Technologies). Conditionally immortalized murine podocyte and murine glomerular endothelial cells were described previously (Mundel et al., 1997; Akis and Madaio, 2004; Psotka et al., 2009) and cultured in RPMI1640 supplemented with 10\% FBS, $2 \mathrm{mM}$ L-glutamine, $100 \mathrm{U} / \mathrm{ml}$ penicillin, $100 \mu \mathrm{g} / \mathrm{ml}$ streptomycin and $80 \mathrm{U} / \mathrm{ml}$ Interferon-gamma (Sigma-Aldrich, St. Louis, $\mathrm{MO})$ at $33^{\circ} \mathrm{C}$ as permissive/undifferentiated condition. The cultures were transferred to $37^{\circ} \mathrm{C}$ and incubated in the media above without IFN- $\gamma$ and allowed to differentiate for 14 days. Differentiated murine podocytes and glomerular endothelial cells were used in the experiments. Mouse NKT cell lines $\mathrm{V} \alpha 14^{+} \mathrm{DN} 32 . \mathrm{D} 3$

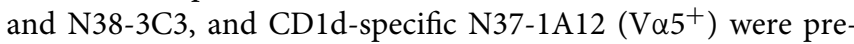
viously described (Lantz and Bendelac, 1994; Brutkiewicz et al., 1995; Burdin et al., 1998; Roberts et al., 2002) and were cultured in Iscove's modified Dulbecco's medium (IMDM) (Life Technologies) supplemented with 5\% FBS and $2 \mathrm{mM}$ L-glutamine. Murine L cells transfected with wild-type Cd1d1 cDNA (LCD1d) or with control vector (L-vector) were described (Chen et al., 1997; Webb et al., 2008) and cultured in Dulbecco's Modified Eagle Medium (DMEM) (Life Technologies) supplemented with $2 \mathrm{mM}$ L-glutamine (Lonza BioWhittaker, Walkersville, 
A

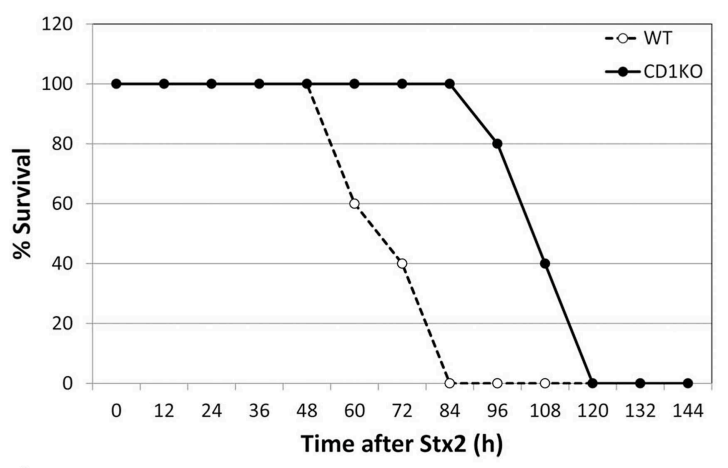

C

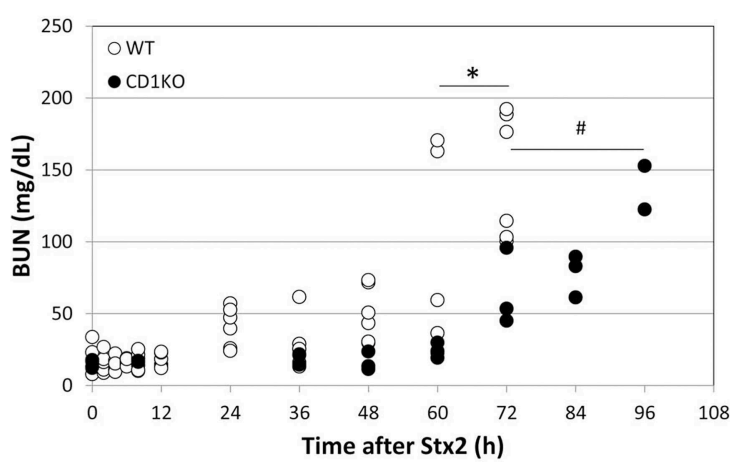

$\mathbf{E}$

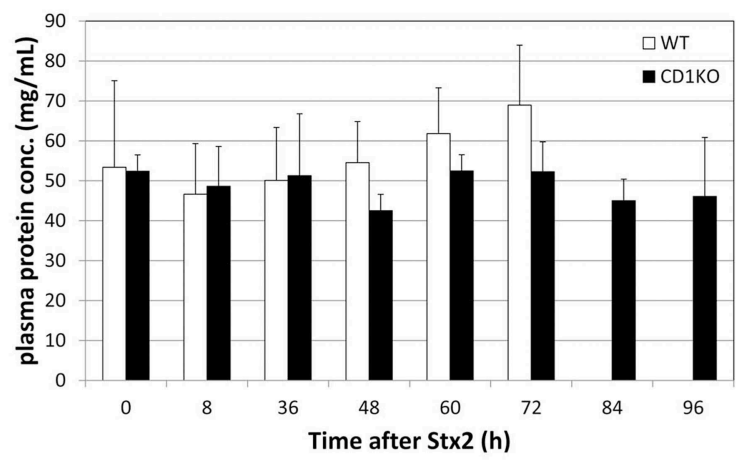

FIGURE 1 | Delay in Stx2-induced pathology in NKT cell deficient mice. (A) Percent survival of WT $(n=5)$ and CD1KO $(n=5)$ after Stx2 injection is plotted. Log-rank (Mantel-Cox) test, $p=0.0042$. (B) Percent weight change of WT $(n=5)$ and CD1KO $(n=5)$ after Stx2 injection is plotted. Error bars are standard deviation. Two-Way ANOVA followed by Bonferroni test, ${ }^{*} p<0.05$. (C) BUN value of each mouse are plotted from $\mathrm{WT}(n=5$ per time point) and CD1KO ( $n=3$ per time point). One-Way ANOVA followed by Tukey test, ${ }^{*} p<0.05$ WT compared to $0 \mathrm{~h},{ }^{*} p<0.05$ CD1KO compared to $0 \mathrm{~h}$. (D) Urinary albumin of WT $(n=2-9$ per time point) and CD1KO ( $n=4-8$ per time point) are plotted for
B

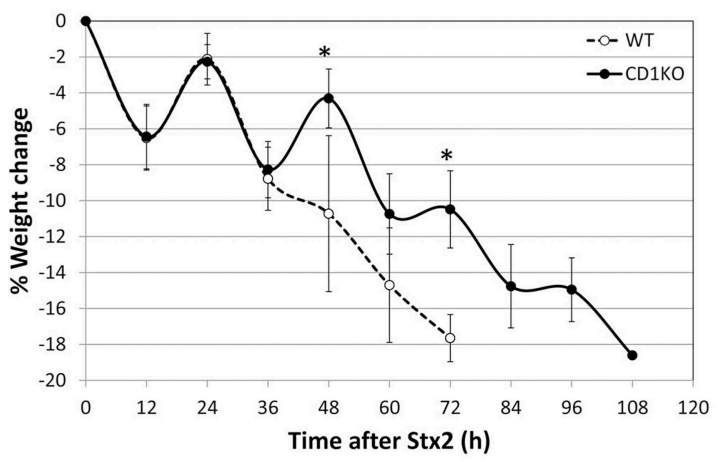

D

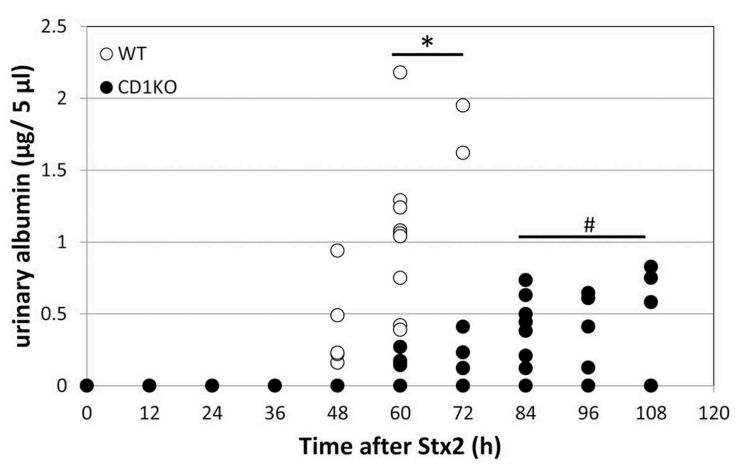

$\mathbf{F}$

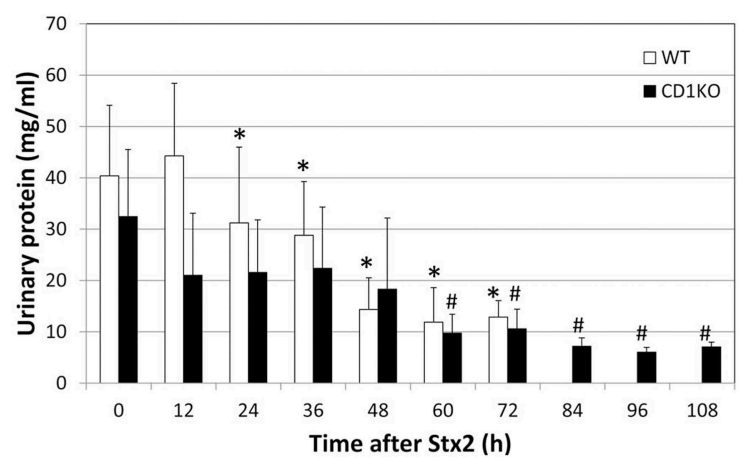

each urine sample obtained at indicated time points. One-Way ANOVA followed by Tukey test, ${ }^{*} p<0.05$ WT compared to $0 \mathrm{~h}$, $\#_{p}<0.05$ CD1KO compared to $0 \mathrm{~h}$. (E) Averages of plasma concentration of WT ( $n=5$ per time point) and CD1KO $(n=3$ per time point) from matching samples to (C) are shown. Error bars are standard deviation. One-Way ANOVA followed by Tukey test and no significance was detected. (F) Averages of urinary protein concentration of WT ( $n=2$ to9 per time point) and CD1KO $(n=4$ to 8 per time point) from matching samples to (D) are shown. One-Way ANOVA followed by Tukey test, ${ }^{*} p<0.05$ WT compared to $\mathrm{Oh}, \#_{p}<0.05$ CD1KO compared to $\mathrm{Oh}$.
MD), 10\% FBS (HyClone) and ciprofloxacin (EMD Millipore, Billerica, MA).

\section{Purification of Stx2 with LPS Removal}

Purification of Stx 2 was kindly provided by Dr. Anne Kane (The Phoenix Lab at Tufts Medical Center, Boston, MA)
(Donohue-Rolfe et al., 1989; Stone et al., 2012). LPS was removed from purified Stx2 by Detoxi-gel from Thermo Fisher Scientific (Rockford, IL, USA) by the manufacturer's protocol. A phosphate buffer saline (PBS)-eluted and $0.2 \mu \mathrm{m}$ filter sterilized Stx2 fraction was tested by Limulus amebocyte lysate assay with detection limit $>0.03$ endotoxin unit (EU)/ml (Pyrotell, Associates of Cape 
Cod Incorporated, East Falmouth, MA, USA). Stx2 solutions for culture experiment and mouse injection were determined to contain less than $0.03 \mathrm{EU} / \mathrm{ml}$ of endotoxin.

\section{BUN Measurement for Renal Failure Evaluation}

EDTA-blood was centrifuged at $3000 \mathrm{~g}$ for $15 \mathrm{~min}$ at $4^{\circ} \mathrm{C}$. Plasma was separated from buffy coat and used for BUN assay. BUN assay was performed following directions of the Urea Assay kit (Abnova Taiwan Corporation, Taipei City, Taiwan) with slight modification; plasma was diluted in molecular grade water and samples were incubated for $40 \mathrm{~min}$ at room temperature, and incubated with agitation for $10 \mathrm{~min}$ at room temperature. Absorption at $520 \mathrm{~nm}$ was read using a microplate reader (Synergy HT, Biotek, Winooski, Vermont). Concentration of Urea $(\mathrm{mg} / \mathrm{dL})$ was calculated based on a Urea standard curve. Urea concentrations were converted to BUN as stated in the manual: $\operatorname{BUN}(\mathrm{mg} / \mathrm{dL})=[$ Urea $(\mathrm{mg} / \mathrm{dL})] / 2.14$.

\section{ELISA}

Cytokine levels in kidney cell lysates from WT or CD1KO mice treated with Stx2 for the indicated time periods were determined by ELISA. A half kidney was homogenized with $1 \mathrm{ml}$ RIPA buffer consisting $50 \mathrm{mM}$ Tris, $150 \mathrm{mM} \mathrm{NaCl}, 1 \%$ igepal CA$630,0.5 \%$ deoxycholic acid supplemented with protease inhibitor cocktail and $1 \mathrm{mM}$ phenylmethylsulfonyl fluoride (PMSF) (all from Sigma-Aldrich). After centrifugation, resulted supernatant (lysate) was used for the assay. Mouse IL-2 ELISA kit from BD Biosciences (San Jose, CA) or mouse IFN- $\gamma$, IL-4 and IL-17 ELISA Max $^{\mathrm{TM}}$ kits from BioLegend (San Diego, CA) were purchased and used as per the manufacturer's directions. Kidney lysates were loaded onto ELISA plates in triplicate and cytokine concentrations were determined using a standard curve. The obtained concentrations were normalized to total protein in the sample and represented as pg of cytokine per mg total protein.

\section{Urine Analyses}

Urine was collected from mice every $12 \mathrm{~h}$ starting at $0 \mathrm{~h}$ (prior to Stx2 injection) or the time of tissue harvesting. In the case of dissection, mice were euthanized by $\mathrm{CO}_{2}$ inhalation and urine was collected directly from the bladder using a needle and syringe. An equal volume of urine $(5 \mu \mathrm{l})$ per lane was analyzed by SDS-PAGE with coomassie brilliant blue (CBB) stain along with known amount of bovine serum albumin (BSA). After densitometry of $66 \mathrm{kDa}$ band (albumin) (Sekine et al., 2012), the amount ( $\mu \mathrm{g}$ ) per $5 \mu \mathrm{l}$ urine was calculated from BSA standard curve. The protein concentration of urine was analyzed by BCA assay (Thermo Fisher Scientific Inc. Rockford, IL).

\section{Immunofluorescence Stain of Stx2-Treated Cells}

Vero cells, differentiated podocytes and differentiated endothelial cells were trypsinized and seeded on glass bottom petri dishes (MatTek, Ashland, MA). After the attachment, cells were incubated with $20 \mathrm{nM}$ Stx 2 for 5 and $15 \mathrm{~min}$ at $37^{\circ} \mathrm{C}$. No toxin added cells $(0 \mathrm{~min})$ were used as toxin negative controls. After the incubation, dishes were placed on the ice, and washed with ice cold phosphate-buffered saline (PBS, Cellgro). Cells were fixed with $4 \%$ parafolmaldehyde (PFA, Sigma-Aldrich)/PBS, washed and blocked with 3\% Bovine serum albumin (BSA, Sigma-Aldrich)/PBS. In order to detect cell surface localization, cells were not permeabilized. Anti-Gb 3 rat monoclonal antibody (clone 38-13, Immunotec/Beckman Coulter, Brea, CA) diluted in $1 \%$ BSA/PBS incubation was followed by PBS wash and antirat IgM-AlexaFluor488 (Life Technologies). After wash, antiStx2A mouse monoclonal antibody (11E10, ATCC) diluted in $1 \%$ BSA/PBS was followed by PBS wash and anti-mouse IgGAlexaFluor647 (Life Technologies). Nuclei were stained with 4,6diamidino-2-phenylindole (DAPI, Life Technologies). Identical dishes were made one for confocal microscopy observation and another for 3D STORM-TIRF observation. Cells were kept in PBS at $4{ }^{\circ} \mathrm{C}$ until microscopic observation.

\section{Confocal Microscopy}

Confocal microscope LSM510 (Carl Zeiss, Thornwood, NY) with Argon $(488 \mathrm{~nm}, 25 \mathrm{~mW})$, Helium Neon $(633 \mathrm{~nm}, 6 \mathrm{~mW})$ and MaiTai $(710 \mathrm{~nm}, 1.5 \mathrm{~W})$ lasers was used to visualize AlexaFluor488, -647, DAPI and differential interference contrast microscopy (DIC). LSM 5 Image Browser was used to acquire and analyze images.

\section{Three Dimensional STORM-TIRF Imaging and Analysis}

Buffer of the cells was changed to STORM-imaging buffer consisting $50 \mathrm{mM}$ Tris- $\mathrm{HCl}(\mathrm{pH} 8.0), 10 \mathrm{mM} \mathrm{NaCl}, 10 \%$ glucose, $5.6 \mathrm{mg} / \mathrm{ml}$ glucose oxidase, $0.17 \mathrm{mg} / \mathrm{ml}$ catalase, $100 \mathrm{mM}$ MEA (cysteamine) (all from Sigma-Aldrich). A $256 \times 256$ pixel field that includes approximately one cell per field was imaged at a time. TIRF degree of 2660 was used in perfect focus 3D STORM setting upon sample bleaching for the certain angles below and above indicated TIRF angle. The sample bleaching is in order to get rid of unspecific signals. Argon $(488 \mathrm{~nm})$ and Helium Neon $(647 \mathrm{~nm})$ lasers were used in $100 \%$ power at acquisition in order to activate all possible fluorescence molecules. A total of 10,000 signals were collected per image. In Nikon NIS-Elements AR software was used to acquire and analyze collected STORM-TIRF images. Diameter of one fluorescence molecule was $0.01 \mu \mathrm{m}$. Twelve 488/647 double positive clusters were measured for the size in molecules. The 488 cluster size was calculated as $39.25 \pm$ 14.97 fluorescence molecules per cluster and the 647 cluster size was calculated as $42.83 \pm 17.93$ fluorescence molecules per cluster. An entire cell was sectioned in $50 \mathrm{~nm} \mathrm{z}$-steps (z-slices) from extracellular to intracellular in the range between -500 and $500 \mathrm{~nm}$, and 488/647 double positive objects that fulfill intensity and area size of the positive clusters in each z-slices were accordingly counted.

\section{In vitro NKT Activation Assay}

Differentiated murine podocytes and endothelial cells were treated with or without $1 \mathrm{nM}$ Stx 2 for $1 \mathrm{~h}$ at $37^{\circ} \mathrm{C}$. Cells $(5 \times$ $10^{5}$ per well) were washed extensively (three times) and loaded with $100 \mathrm{ng} / \mathrm{ml}$ of $\alpha$-GalCer purchased from Avanti Polar Lipids (Alabaster, $\mathrm{AL}$ ) for $2 \mathrm{~h}$ at $37^{\circ} \mathrm{C}$ in IMDM supplemented with $5 \%$ FBS and $2 \mathrm{mM}$ L-glutamine from Life Technologies (Carlsbad, CA). After this lipid antigen loading step, cells were washed again and co-cultured with DN32.D3 (type I), N37-1A12 (type II) or 
N38-3C3 (type I) NKT cell hybridomas $\left(5 \times 10^{4}\right.$ per well) in the same medium. Medium alone and L-vector, a mouse fibroblast cell line transfected with empty vector were used as negative controls. L-CD1d, a mouse fibroblast cell line transfected with CD1d and known to present an unknown, endogenous, strongly activating antigen to NKT cells was used as a positive control. The coculture was set up in triplicate in 96-well microtiter plates for $20 \mathrm{~h}$ at $37^{\circ} \mathrm{C}$. Following the coculture, supernatants were harvested and IL-2 levels, which are indicative of NKT cell activation were measured by ELISA, as described above (Webb et al., 2006).

\section{Flow Cytometry}

Cells were stained in staining buffer (PBS containing 0.5\% BSA and $2 \mathrm{mM}$ EDTA) for $30 \mathrm{~min}$ at $4{ }^{\circ} \mathrm{C}$ with phycoerythrin (PE)conjugated anti-CD1d antibody (clone 1B1) or the respective isotype control from BD Biosciences in accordance with the manufacturer's directions. After staining, cells were washed three times with staining buffer and analyzed immediately by flow cytometry. Data were collected on an LSR II from BD Biosciences and analyzed using FCS Express Version 3 from De Novo Software (Los Angeles, CA).

\section{Statistical Analyses}

One-Way ANOVA followed by Tukey test was performed with the time course series samples compared to $0 \mathrm{~h}$ value. $P$-values less than 0.05 was determined as significant. Two-Way ANOVA followed by Bonferroni test was used for compare two strains (WT vs. CD1KO), and $p$-values less than 0.05 was determined as significant. All statistical analyses were performed using GraphPad Prism 5.04 software (GraphPad Software, Inc., La Jolla, CA).

\section{Results}

\section{Stx2-Induced Pathologies were Delayed in CD1KO Mice}

In order to determine whether NKT cells contribute to Stx2mediated disease, C57BL/6 (WT) mice and CD1KO (NKT cell deficient) mice were treated with Stx2 (i.p.,) and mortality, weight loss, BUN, urinary albumin, urinary protein, and serum protein were measured (Figure 1). The survival of CD1KO mice injected with Stx2 was prolonged twice as much compared to WT (Figure 1A). Similarly, Stx2-induced weight loss occurred more rapidly in WT mice compared to CD1KO mice, with $10 \%$ weight loss occurring in WT mice by $48 \mathrm{~h}$ post-treatment, while in CD1KO mice it did not occur until $72 \mathrm{~h}$ (Figure 1B). Differences were also detected in renal function. BUN was significantly increased in WT mice $60 \mathrm{~h}$ after Stx 2 injection, whereas in CD1KO mice, significant increase of BUN was seen after $72 \mathrm{~h}$ (Figure 1C). Plasma total protein concentrations in both WT and CD1KO did not change throughout the time course (Figure 1E) emphasizing the significance of BUN increase in Stx2 injected animal. Furthermore, urinary albumin was increased after $60 \mathrm{~h}$ of Stx 2 injection in WT, whereas it increased after $84 \mathrm{~h}$ in CD1KO (Figure 1D). Total urinary protein was reduced in WT $24 \mathrm{~h}$ post Stx 2 injection, and the reduction was delayed in
CD1KO mice, as it occurred after $60 \mathrm{~h}$ (Figure 1F). These delays observed in CD1KO strongly suggest NKT cell involvement in the acceleration of Stx2 pathology.

\section{Stx2-Induced Renal Cytokine Response is Delayed in CD1KO Mice}

Given the delay in Stx2-pathologies in CD1KO mice, we suspected the induction of NKT cell-associated inflammation in kidney. NKT cells produce cytokines such as IL-2, IL-4, IFN- $\gamma$, and IL-17. Kidney lysates of Stx2-injected mice were analyzed for these cytokines (Figure 2). In WT mice, IL-2, IL-4, IFN- $\gamma$, and IL17 showed increase after $8 \mathrm{~h}$ and peaked at $36-48 \mathrm{~h}$ following Stx 2 injection. In line with previous markers of Stx2-mediated pathology in CD1KO mice, significant increases in these cytokines were noted later at $60 \mathrm{~h}$. These data suggest that NKT cell activation contributes to accelerate Stx 2 renal pathology by promoting inflammation.

\section{Stx2 Binds to Mouse Renal Glomerular Cells In vitro}

In kidney, the first cell types that NKT cells as well as Stx2 may encounter are glomerular cells, such as endothelial cells and podocytes. We tested the possibility of Stx2 directly interacting with murine glomerular cells by using sensitive fluorescence imaging methods. Murine glomerular podocytes and Vero cells were incubated with Stx2 and the localization of Stx2 (red) and the receptor $\mathrm{Gb}_{3}$ (green) was observed by confocal microscopy. Without Stx2, podocytes had none to minimum level of red, whereas $\mathrm{Gb}_{3}$ was clearly positive (Figure $\mathbf{3 A}, 0 \mathrm{~min}$ ) and the result was similar in Vero cells (Figure 3B, 0 min). In all NKT cell hypbridomas tested, $\mathrm{Gb}_{3}$ immunofluorescence was undetectable (data not shown). Stx 2 incubation of 5 and 15 min resulted in cell surface Stx2 localization in both podocytes and Vero cells (arrowheads, Figures 3A,B, 5 and $15 \mathrm{~min}$ ). To observe the precise contact of $S t x 2$ and $\mathrm{Gb}_{3}$ molecules at the plasma membrane, 3D STORM-TIRF was utilized. In 3D STORM-TIRF observation, occurrences of Stx2 (red) and $\mathrm{Gb}_{3}$ (green) contact can be visualized as yellow clusters (Figure 3C, whole cell view). The occurrence of yellow clusters in Vero cells, podocytes and endothelial cells are shown in Table 1. Because the whole cell view looks at all signals from the top of $\mathrm{z}$-sections and STORM detects individual fluorescence as single molecule, a close up of a yellow cluster shows more precise three dimensional positioning of Stx2 (red) and $\mathrm{Gb}_{3}$ (green) (Figure 3C, yellow cluster view). The $360^{\circ}$ of a yellow cluster view is presented as a movie (Supplemental Figure 1). In the yellow cluster depth view, the colors are assigned according to the depth of the molecules from outside of the cell as Red (distance $-500 \mathrm{~nm}$ from plasma membrane) to inside of the cells as blue (distance $500 \mathrm{~nm}$ from plasma membrane) (Figure 3C, yellow cluster depth view, $360^{\circ}$ appearance in Supplemental Figure 2). For example, 0 min sample in which Stx2 is not added, a yellow cluster that occurs occasionally as background is shown in the depth view that colored as green to yellow (membrane to extracellular). In the samples of 5 and $15 \mathrm{~min}$, representative yellow clusters are blue to green (intracellular to membrane) in the depth view. To show the distribution of yellow clusters along with the depth scale, the yellow clusters from each 
A

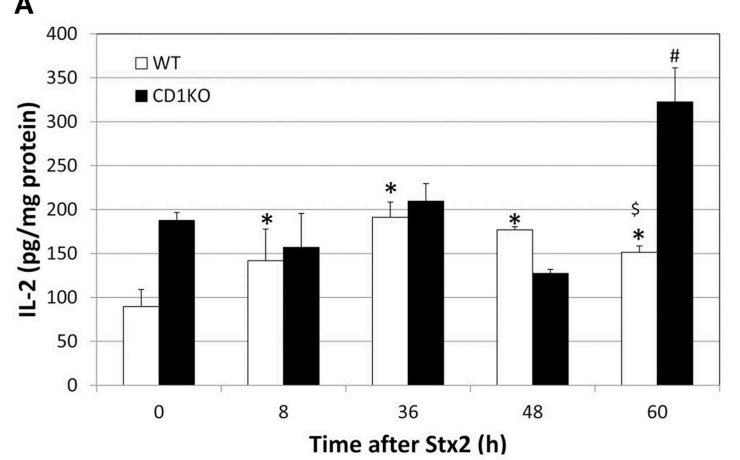

C

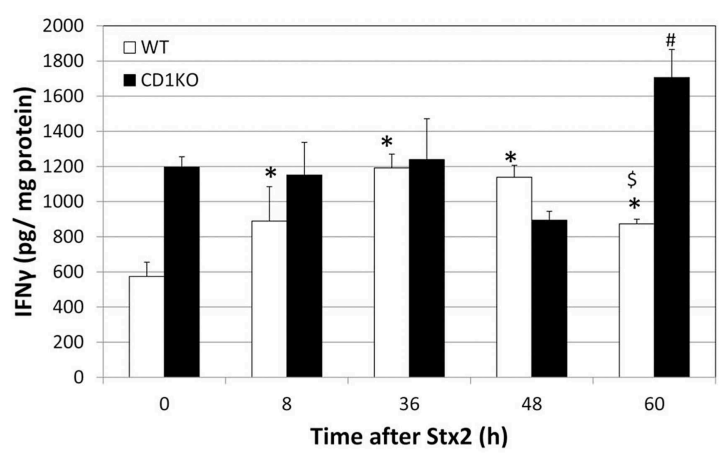

FIGURE 2 | CD1KO mice show delayed renal cytokine release following treatment with Stx2. (A-D) WT ( $n=3$ per time point) or CD1KO ( $n=3$ per time point) mice were treated with Stx2 for the indicated time periods. Kidney lysates from both treatment groups at the indicated time points were analyzed by ELISA and (A) IL-2, (B) IL-4, (C) IFN- $\gamma$ and

\section{B}

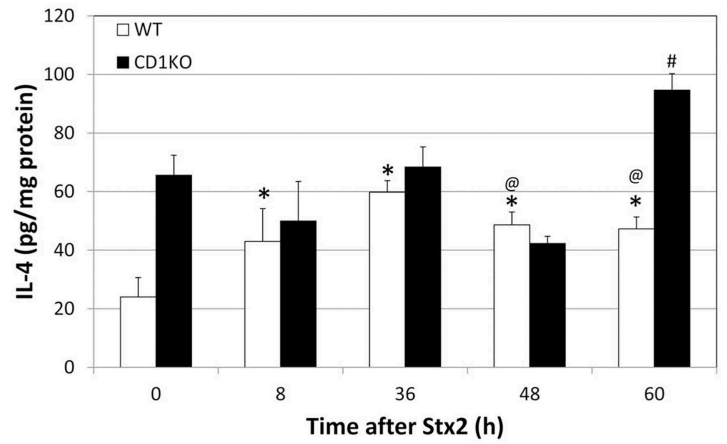

D

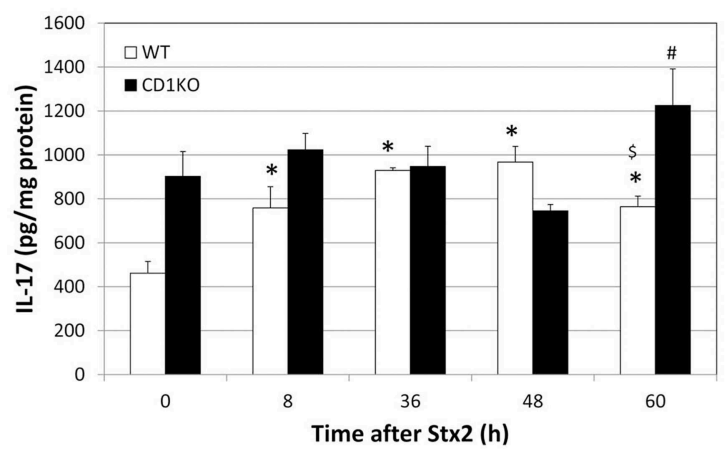

(D) IL-17 concentrations were determined. Results were normalized to total protein and have been represented as pg of cytokine per mg total protein. One-Way ANOVA followed by Tukey test, ${ }^{*} p<0.001$ vs. WT $0 \mathrm{~h}$, $\$ p<0.001$ vs. WT $36 \mathrm{~h}, @ p<0.05$ vs. WT $36 \mathrm{~h}$ and $\# p<0.001$ vs. CD1KO Oh.
$\mathrm{Z}$-section of an entire cell were counted, and shown in contact count graphs (Figure 3C, contact count). The graph plots depth information in $\mathrm{x}$-axis, and cluster counts in $\mathrm{y}$-axis. The results depicts the distribution of $S t x 2 / \mathrm{Gb}_{3}$ double positive clusters that the longer Stx2 was incubated with the cells, the more cluster counts were obtained and the clusters internalized deeper in the cells. Murine glomerular endothelial cells and Vero cells showed similar results (Supplemental Figure 3). Negative controls such as fluorescence-conjugated secondary antibodies are omitted, had only residual signals of AlexaFluor 647 or 488, and the yellow cluster observation was none to minimum (Supplemental Figure 4).

\section{Stx2-Treated Mouse Glomerular Cells Activate NKT Cells}

CD1d-restricted NKT cells can be activated by recognizing lipid antigen that is presented in the context of CD1d molecules that are expressed on antigen presenting cells. The ability of Stx2treated murine renal glomerular cells to induce NKT cell activation was measured by ELISA. Podocytes (Figure 4A) or endothelial cells (Figure 4B) were incubated with or without Stx2, and $\alpha \mathrm{GC}$ was added as a lipid antigen, then co-cultured with NKT cells. Stx2-treated cells with $\alpha \mathrm{GC}$ induced higher levels of IL-2, compared to the no toxin control in the presence of an exogenous antigen, $\alpha \mathrm{GC}(p<0.001)$. Without $\alpha \mathrm{GC}$, both Stx2-treated and non-treated cells did not induce IL- 2 production by NKT cells. The positive control, mouse L-cells stably transfected with $m C D 1 d 1$ (L-CD1d) induced IL-2 production in all NKT cell hybridomas. In order to determine whether an increase in NKT activation in Stx2-treated cells is due to an increase in CD1d surface expression, flow cytometry was performed with podocytes (Figure 4C) or endothelial cells (Figure 4D). Addition of Stx2 did not change the surface expression of CD1d in podocytes or endothelial cells, suggesting an increase in NKT activation in Stx2-treated renal cells is not due to an increased the levels of CD1d.

\section{Discussion}

We demonstrated for the first time that NKT cells accelerate Stx2-pathology in mice. Mice with normal numbers of NKT cells had higher levels of cytokine early after treatment IL-2, IL-4, IFN- $\gamma$, and IL-17 in mouse kidney with subsequent renal failure as well as urine abnormality. In STEC-HUS patients, serum levels of IL-2, IL-4, and IFN- $\gamma$ were similar to the healthy control group (Shiraishi et al., 2008), however the tissue cytokine levels have not been studied. In the non-human primate that maybe the closest model to humans, IL-2, IL-4, IFN- $\gamma$, and 

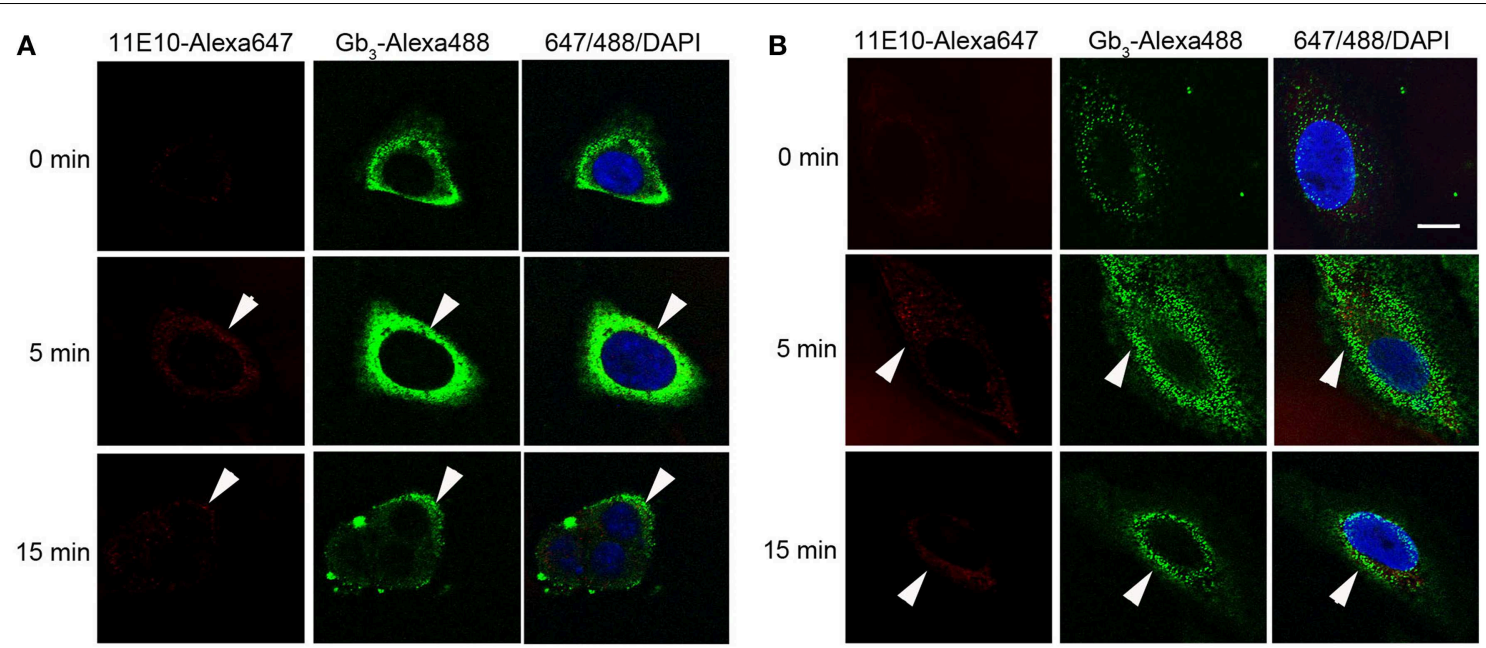

C

whole cell view
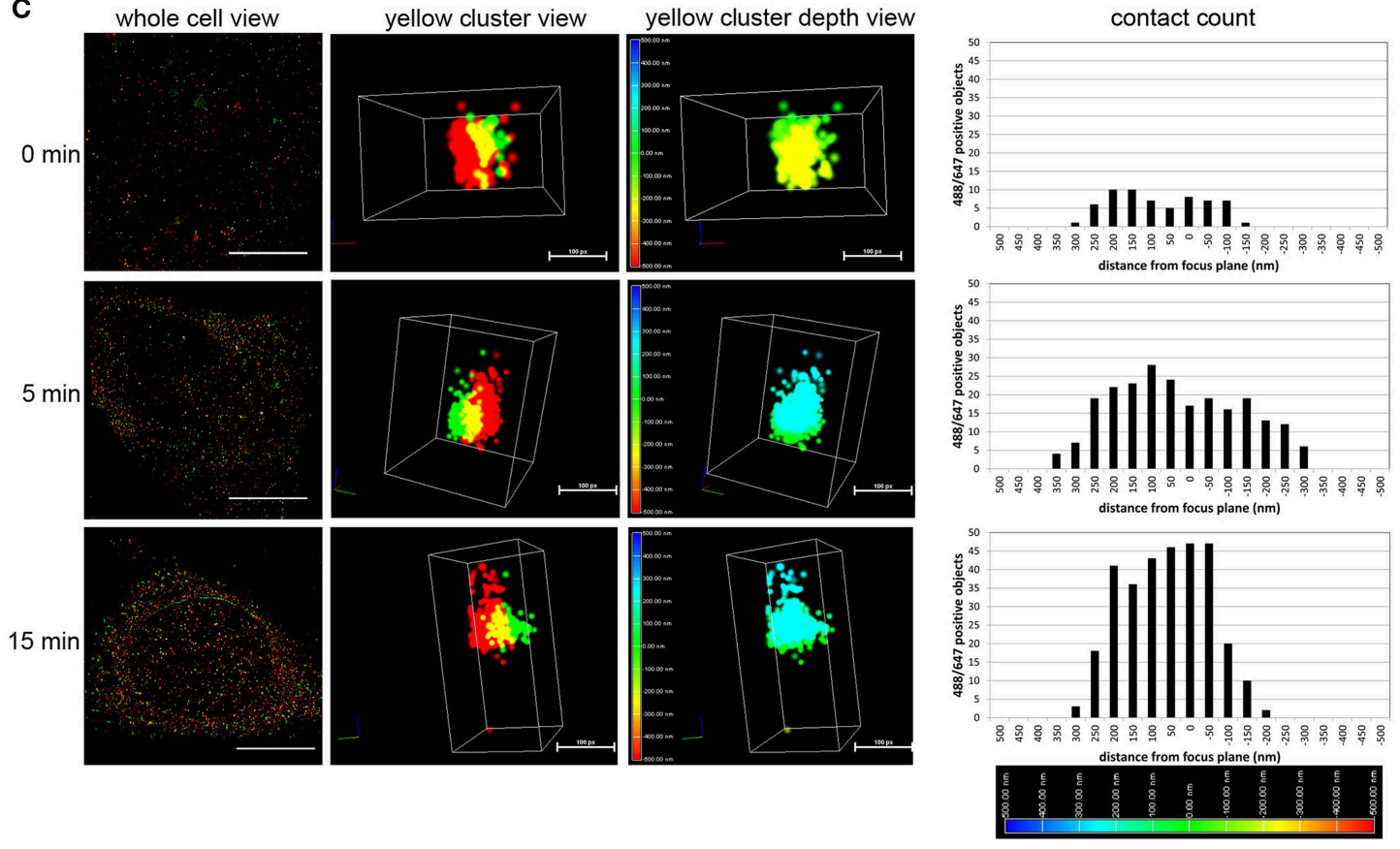

FIGURE 3 | Stx2 interacts with murine glomerular renal cells in vitro. (A) Murine podocytes or (B) Vero cells were incubated with $20 \mathrm{nM}$ Stx2 for 0 (no toxin), 5 and $15 \mathrm{~min}$ at $37^{\circ} \mathrm{C}$. Stx2 was labeled with monoclonal antibody $11 \mathrm{E} 10$ followed by anti-mouse IgG-AlexaFluor 647 (pseudo colored red) and $\mathrm{Gb}_{3}$ was labeled with monoclonal antibody 38.13 followed by anti-rat IgM-AlexaFluor 488 (green). Nuclei were stained with DAPI (blue). Samples were observed with confocal microscopy. Representative cells that are chosen from each time point group are shown. Bars indicate $10 \mu \mathrm{m}$. Arrowheads point

Stx2-AlexaFluor 647 positive cells. (C) Murine podocytes were incubated with $20 \mathrm{nM}$ Stx2 for 0 (no toxin), 5 and $15 \mathrm{~min}$ at $37^{\circ} \mathrm{C}$ and labeled as above. Samples were visualized with 3D STORM-TIRF microscopy and analyzed using Nikon Elements software. Whole cell view presents representative cells from each time point. Bars are $10 \mu \mathrm{m}$. Yellow spot view presents highly magnified and three dimensionally shown yellow cluster (red $=$ Stx2-Alexa647, green $=\mathrm{Gb}_{3}$-Alexa488 and yellow $=$ red and green overlapping pixels). Bars are 100 pixels (px). Yellow cluster depth view depicts the intra or extracellular depth of the yellow cluster. The color-coded depth scale at the left differentiate the distance $(\mathrm{nm})$ from the focus plane $(0 \mathrm{~nm}$, green). Blue represents intracellular (up to $500 \mathrm{~nm}$ ) whereas red represents extracellular (up to $-500 \mathrm{~nm}$ ). Contact count given in the graphs presents amount and depth distribution of green and red contact of a whole cell. The color-coded depth scale at the bottom indicates intracellular (blue) to extracellular (red).
IL-17 were not detectable after Shiga toxins injection (StearnsKurosawa et al., 2010). In this model, serum IL-12/23 was also not detectable after Shiga toxins injection, but IL-12 mRNA was upregulated in kidneys (Stearns-Kurosawa et al., 2013). This suggests that there is a renal specific inflammation after Shiga toxins injection. NKT cells also produce RANTES and MIP1- $\alpha$ (Chang et al., 2007), which have been implicated in the mouse model of HUS (Keepers et al., 2007; Sauter et al., 2008). NKT cells 
produce cytokines that can recruit or activate neutrophils (Nakamatsu et al., 2007) and macrophages (Kronenberg and Gapin, 2002), and they are also implicated in Stx2-associated mice renal pathology (Keepers et al., 2007; Roche et al., 2007). Thus, Stx2associated NKT activation in the kidney may explain rapid renal recruitment of neutrophils and macrophages to induce further inflammation.

In vitro, we showed that murine renal glomerular podocytes and endothelial cells express functional CD1d. NKT cells were able to recognize the lipid antigen $\alpha \mathrm{GC}$ :CD1d complexes on renal cells and this lead to increased levels of IL-2 when renal cells were

TABLE 1 | Cells with yellow clusters (488/647 positive clusters) in 3D STORM-TIRF observation. ${ }^{\text {a }}$

\begin{tabular}{llll}
\hline & $\mathbf{0} \boldsymbol{m i n}(\%)$ & $\mathbf{5} \boldsymbol{m i n}(\%)$ & $\mathbf{1 5} \mathbf{m i n}(\%)$ \\
\hline Vero cell & $0 / 3(0)$ & $2 / 4(50)$ & $2 / 12(17)$ \\
Podocyte & $2 / 3(66)^{\mathrm{b}}$ & $1 / 3(33)$ & $2 / 8(25)$ \\
Endothelial cell & $2 / 3(66)^{\mathrm{b}}$ & $2 / 3(66)$ & $2 / 3(66)$ \\
\hline
\end{tabular}

aWhen more than one yellow cluster is observed in one cell, it is counted as a yellow cluster positive cell. However, the frequency or the total numbers of yellow clusters in the cell or the distribution of the clusters, whether they are intracellular or extracellular, is not reflected in this table. Examples of numbers and distributions of yellow clusters are shown in Figure 3C.

${ }^{b} 488 / 647$ overlap clusters are minimum number and/or extracellular. treated with Stx2. Activation of NKT cells were only seen in the presence of $\alpha \mathrm{GC}$, this suggests murine renal cells do not present an activating self-antigen (endogenous lipid antigen) after $1 \mathrm{~h}$ of Stx2 treatment. However, this may be the result of the short treatment time $(1 \mathrm{~h})$ and longer incubations with Stx 2 might result in change in the repertoire of lipid antigens. Furthermore, expression levels of CD1d in both types of renal cells were not altered following treatment with Stx2. The mechanism by which Stx2 treatment leads to enhance CD1d-mediated NKT cell activation needs further investigation. In bacterial infection, lipopolysaccharide (LPS) has been shown to interact with toll-like receptor 4 (TLR4) of dendritic cells (DCs) and induce NKT cell activation in the absence of an activating bacterial antigen, but is dependent on the secretion of IL-12 by DC (Brigl et al., 2003; Mattner et al., 2005). As our Stx2 fraction is free of LPS, therefore LPSinduced IL-12 is not responsible for these changes in NKT cell responses; however, our data indicates that Stx 2 may induce a co-stimulator(s) factor in renal cells to activate NKT cells.

We presented evidence showing the direct interaction of Stx2 with murine podocyte $\mathrm{Gb}_{3}$ in a single molecule imaging analysis known as 3D STORM-TIRF. In traditional light microscopy, the resolution is limited by diffraction and the ability of the microscope to separate objects that are more than $200 \mathrm{~nm}$ apart. Whereas, electron microscopy gives higher resolution in nanometer ranges with a tradeoff of longer processing of samples. The STORM technique enables fluorescence imaging to be

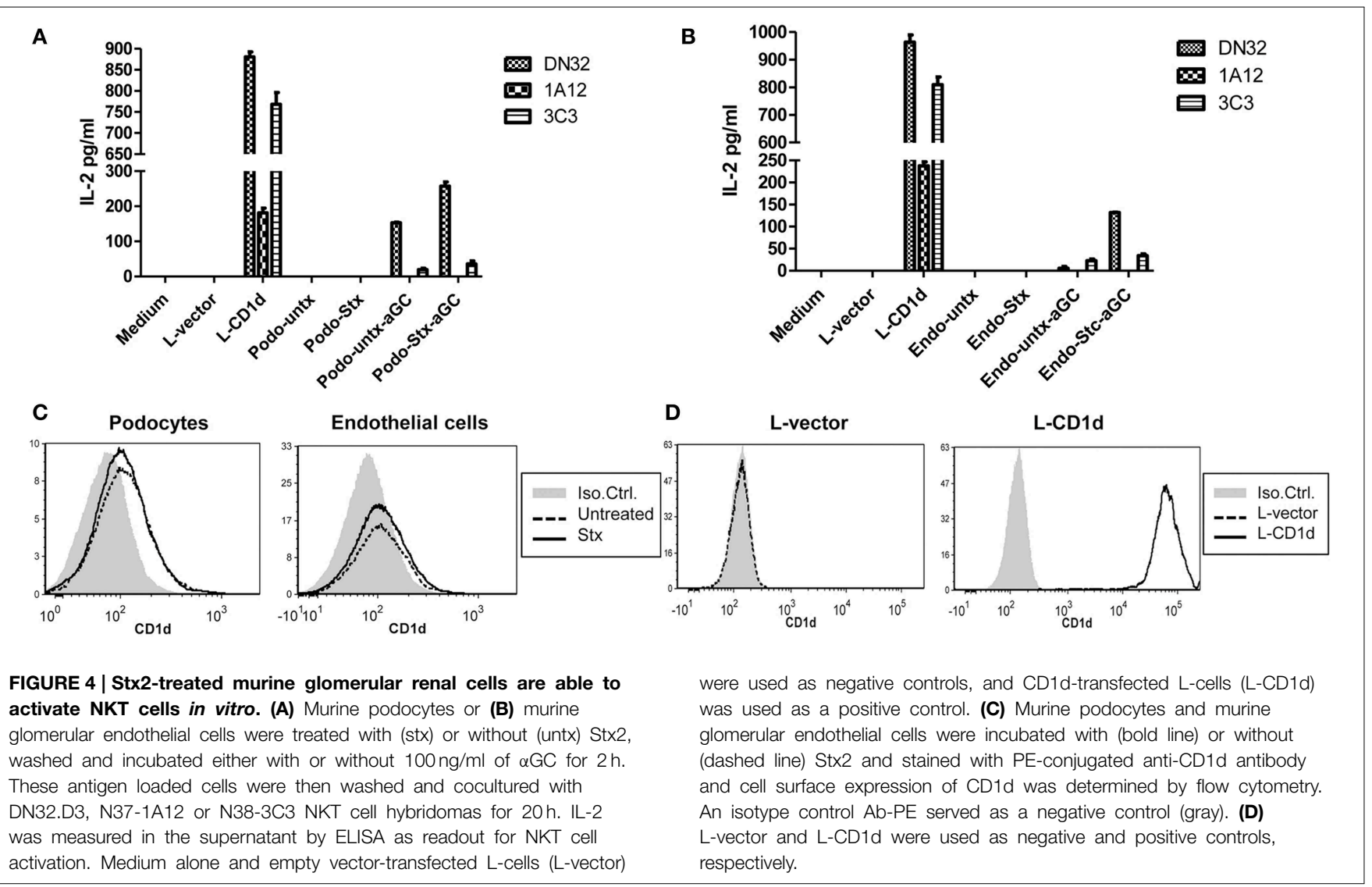


close to the resolution obtained using electron microscopy by calculating the fluorescence source to its exact position and 3D function allows precise depth information of molecules that are close to plasma membrane in conjunction with TIRF function. To study cell types that are resistant to Shiga toxins but respond by other biological measures, like cytokine production by Stx1treated human monocytes (Ramegowda and Tesh, 1996), this state of the art imaging technique is an effective tool to provide evidence of the direct interaction of toxin binding to its receptor.

In summary, our data support a model where NKT cells contribute to Stx2-associated renal pathology and lethality. Furthermore, our data suggests that Stx interactions with glomerular cells may promote CD1d-mediated NKT cell activation. Therefore, we hypothesize that NKT cells may accelerate progression to renal failure during STEC infection through Stx2-effects on renal endothelium and podocytes that potentiate NKT-cell activation and result in increased inflammatory signaling. If NKT cells do potentiate inflammation and renal failure during STEC infection,

\section{References}

Ake, J. A., Jelacic, S., Ciol, M. A., Watkins, S. L., Murray, K. F., Christie, D. L., et al. (2005). Relative nephroprotection during Escherichia coli O157:H7 infections: association with intravenous volume expansion. Pediatrics 115, e673-e680. doi: 10.1542/peds.2004-2236

Akis, N., and Madaio, M. P. (2004). Isolation, culture, and characterization of endothelial cells from mouse glomeruli. Kidney Int. 65, 2223-2227. doi: 10.1111/j.1523-1755.2004.00634.x

Berzins, S. P., Smyth, M. J., and Baxter, A. G. (2011). Presumed guilty: natural killer T cell defects and human disease. Nat. Rev. Immunol. 11, 131-142. doi: $10.1038 /$ nri2904

Brigl, M., Bry, L., Kent, S. C., Gumperz, J. E., and Brenner, M. B. (2003). Mechanism of CD1d-restricted natural killer $\mathrm{T}$ cell activation during microbial infection. Nat. Immunol. 4, 1230-1237. doi: 10.1038/ni1002

Brutkiewicz, R. R., Bennink, J. R., Yewdell, J. W., and Bendelac, A. (1995). TAPindependent, beta 2-microglobulin-dependent surface expression of functional mouse CD1.1. J. Exp. Med. 182, 1913-1919. doi: 10.1084/jem.182.6.1913

Burdin, N., Brossay, L., Koezuka, Y., Smiley, S. T., Grusby, M. J., Gui, M., et al. (1998). Selective ability of mouse CD1 to present glycolipids: alphagalactosylceramide specifically stimulates $\mathrm{V}$ alpha $14+\mathrm{NK} \mathrm{T}$ lymphocytes. J. Immunol. 161, 3271-3281.

Carnaud, C., Lee, D., Donnars, O., Park, S. H., Beavis, A., Koezuka, Y., et al. (1999). Cutting edge: cross-talk between cells of the innate immune system: NKT cells rapidly activate NK cells. J. Immunol. 163, 4647-4650.

Chang, Y. J., Huang, J. R., Tsai, Y. C., Hung, J. T., Wu, D., Fujio, M., et al. (2007). Potent immune-modulating and anticancer effects of NKT cell stimulatory glycolipids. Proc. Natl. Acad. Sci. U.S.A. 104, 10299-10304. doi: 10.1073/pnas.0703824104

Chen, H., Huang, H., and Paul, W. E. (1997). NK1.1+ CD4+ T cells lose NK1.1 expression upon in vitro activation. J. Immunol. 158, 5112-5119.

Dempsey, G. T., Vaughan, J. C., Chen, K. H., Bates, M., and Zhuang, X. (2011). Evaluation of fluorophores for optimal performance in localization-based super-resolution imaging. Nat. Methods 8, 1027-1036. doi: 10.1038/nmeth.1768

Dervenoulas, J., Tsirigotis, P., Bollas, G., Pappa, V., Xiros, N., Economopoulos, T., et al. (2000). Thrombotic thrombocytopenic purpura/hemolytic uremic syndrome (TTP/HUS): treatment outcome, relapses, prognostic factors. A single-center experience of 48 cases. Ann. Hematol. 79, 66-72. doi: $10.1007 / \mathrm{s} 002770050012$

Donohue-Rolfe, A., Acheson, D. W., Kane, A. V., and Keusch, G. T. (1989). Purification of Shiga toxin and Shiga-like toxins I and II by receptor analog affinity chromatography with immobilized P1 glycoprotein and production of cross-reactive monoclonal antibodies. Infect. Immun. 57, 3888-3893. inhibition of NKT-cell activation may be a therapeutic strategy to prevent or delay the progression of STEC-associated systemic disease such as HUS.

\section{Acknowledgments}

We appreciate Dr. Tom Obrig for careful reading of this manuscript and precious input of his opinion. This study was supported by funding from United States Public Health Service grant AI075778 and AI090144 to FO, and NIH/NCI K01 CA131487, R21 CA162273, and R21 CA162277 to TW.

\section{Supplementary Material}

The Supplementary Material for this article can be found online at: http://www.frontiersin.org/journal/10.3389/fmicb. 2015.00262/abstract
Fernandez, G. C., Gomez, S. A., Rubel, C. J., Bentancor, L. V., Barrionuevo, P., Alduncin, M., et al. (2005). Impaired neutrophils in children with the typical form of hemolytic uremic syndrome. Pediatr. Nephrol. 20, 1306-1314. doi: 10.1007/s00467-005-1906-9

Fernandez, G. C., Lopez, M. F., Gomez, S. A., Ramos, M. V., Bentancor, L. V., Fernandez-Brando, R. J., et al. (2006). Relevance of neutrophils in the murine model of haemolytic uraemic syndrome: mechanisms involved in Shiga toxin type 2-induced neutrophilia. Clin. Exp. Immunol. 146, 76-84. doi: $10.1111 / j .1365-2249.2006 .03155 . x$

Gianantonio, C. A., Vitacco, M., Mendilaharzu, F., Gallo, G. E., and Sojo, E. T. (1973). The hemolytic-uremic syndrome. Nephron 11, 174-192. doi: $10.1159 / 000180229$

Hua, J., Liang, S., Ma, X., Webb, T. J., Potter, J. P., and Li, Z. (2011). The interaction between regulatory $\mathrm{T}$ cells and NKT cells in the liver: a CD1d bridge links innate and adaptive immunity. PLoS ONE 6:e27038. doi: 10.1371/journal.pone. 0027038

Karmali, M. A., Petric, M., Lim, C., Fleming, P. C., Arbus, G. S., and Lior, H. (1985). The association between idiopathic hemolytic uremic syndrome and infection by verotoxin-producing Escherichia coli. J. Infect. Dis. 151, 775-782. doi: 10.1093/infdis/151.5.775

Kawano, T., Cui, J., Koezuka, Y., Toura, I., Kaneko, Y., Motoki, K., et al. (1997). CD1d-restricted and TCR-mediated activation of valpha14 NKT cells by glycosylceramides. Science 278, 1626-1629. doi: 10.1126/science.278.534 3.1626

Keepers, T. R., Gross, L. K., and Obrig, T. G. (2007). Monocyte chemoattractant protein 1, macrophage inflammatory protein 1 alpha, and RANTES recruit macrophages to the kidney in a mouse model of hemolyticuremic syndrome. Infect. Immun. 75, 1229-1236. doi: 10.1128/IAI.01 663-06

Keepers, T. R., Psotka, M. A., Gross, L. K., and Obrig, T. G. (2006). A murine model of HUS: Shiga toxin with lipopolysaccharide mimics the renal damage and physiologic response of human disease. J. Am. Soc. Nephrol. 17, 3404-3414. doi: 10.1681/ASN.2006050419

Kronenberg, M., and Gapin, L. (2002). The unconventional lifestyle of NKT cells. Nat. Rev. Immunol. 2, 557-568. doi: 10.1038/nri854

Lantz, O., and Bendelac, A. (1994). An invariant T cell receptor alpha chain is used by a unique subset of major histocompatibility complex class I-specific CD4+ and CD4-8- T cells in mice and humans. J. Exp. Med. 180, 1097-1106. doi: 10.1084/jem.180.3.1097

Liesche, J., Ziomkiewicz, I., and Schulz, A. (2013). Super-resolution imaging with Pontamine Fast Scarlet 4BS enables direct visualization of cellulose orientation and cell connection architecture in onion epidermis cells. BMC Plant Biol. 13:226. doi: 10.1186/1471-2229-13-226 
Lopez, E. L., Diaz, M., Grinstein, S., Devoto, S., Mendilaharzu, F., Murray, B. E., et al. (1989). Hemolytic uremic syndrome and diarrhea in Argentine children: the role of Shiga-like toxins. J. Infect. Dis. 160, 469-475. doi: 10.1093/infdis/160.3.469

Martin, D. L., Macdonald, K. L., White, K. E., Soler, J. T., and Osterholm, M. T. (1990). The epidemiology and clinical aspects of the hemolytic uremic syndrome in Minnesota. N. Engl. J. Med. 323, 1161-1167. doi: 10.1056/NEJM199010253231703

Matsuda, J. L., Mallevaey, T., Scott-Browne, J., and Gapin, L. (2008). CD1drestricted iNKT cells, the "Swiss-Army knife" of the immune system. Curr. Opin. Immunol. 20, 358-368. doi: 10.1016/j.coi.2008.03.018

Mattner, J., Debord, K. L., Ismail, N., Goff, R. D., Cantu, C. III., Zhou, D., et al. (2005). Exogenous and endogenous glycolipid antigens activate NKT cells during microbial infections. Nature 434, 525-529. doi: 10.1038/nature03408

Morigi, M., Buelli, S., Zanchi, C., Longaretti, L., Macconi, D., Benigni, A., et al. (2006). Shigatoxin-induced endothelin-1 expression in cultured podocytes autocrinally mediates actin remodeling. Am. J. Pathol. 169, 1965-1975. doi: 10.2353/ajpath.2006.051331

Mundel, P., Reiser, J., Zuniga Mejia Borja, A., Pavenstadt, H., Davidson, G. R., Kriz, W., et al. (1997). Rearrangements of the cytoskeleton and cell contacts induce process formation during differentiation of conditionally immortalized mouse podocyte cell lines. Exp. Cell Res. 236, 248-258. doi: 10.1006/excr.1997.3739

Murata, A., Shimazu, T., Yamamoto, T., Taenaka, N., Nagayama, K., Honda, T., et al. (1998). Profiles of circulating inflammatory- and anti-inflammatory cytokines in patients with hemolytic uremic syndrome due to E. coli O157 infection. Cytokine 10, 544-548. doi: 10.1006/cyto.1997.0329

Nakamatsu, M., Yamamoto, N., Hatta, M., Nakasone, C., Kinjo, T., Miyagi, K., et al. (2007). Role of interferon-gamma in Valpha14+ natural killer T cellmediated host defense against Streptococcus pneumoniae infection in murine lungs. Microbes Infect. 9, 364-374. doi: 10.1016/j.micinf.2006.12.003

Ostroff, S. M., Tarr, P. I., Neill, M. A., Lewis, J. H., Hargrett-Bean, N., and Kobayashi, J. M. (1989). Toxin genotypes and plasmid profiles as determinants of systemic sequelae in Escherichia coli O157:H7 infections. J. Infect. Dis. 160, 994-998. doi: 10.1093/infdis/160.6.994

Park, S. H., Guy-Grand, D., Lemonnier, F. A., Wang, C. R., Bendelac, A., and Jabri, B. (1999). Selection and expansion of CD8alpha/alpha(1) T cell receptor alpha/beta(1) intestinal intraepithelial lymphocytes in the absence of both classical major histocompatibility complex class I and nonclassical CD1 molecules. J. Exp. Med. 190, 885-890. doi: 10.1084/jem.190.6.885

Perez, N., Spizzirri, F., Rahman, R., Suarez, A., Larrubia, C., and Lasarte, P. (1998). Steroids in the hemolytic uremic syndrome. Pediatr. Nephrol. 12, 101-104. doi: $10.1007 / \mathrm{s} 004670050413$

Petruzziello-Pellegrini, T. N., Yuen, D. A., Page, A. V., Patel, S., Soltyk, A. M., Matouk, C. C., et al. (2012). The CXCR4/CXCR7/SDF-1 pathway contributes to the pathogenesis of Shiga toxin-associated hemolytic uremic syndrome in humans and mice. J. Clin. Invest. 122, 759-776. doi: 10.1172/JCI57313

Proulx, F., Turgeon, J. P., Litalien, C., Mariscalco, M. M., Robitaille, P., and Seidman, E. (1998). Inflammatory mediators in Escherichia coli O157:H7 hemorrhagic colitis and hemolytic-uremic syndrome. Pediatr. Infect. Dis. J. 17, 899-904. doi: 10.1097/00006454-199810000-00010

Psotka, M. A., Obata, F., Kolling, G. L., Gross, L. K., Saleem, M. A., Satchell, S. C., et al. (2009). Shiga toxin 2 targets the murine renal collecting duct epithelium. Infect. Immun. 77, 959-969. doi: 10.1128/IAI.00679-08

Ramegowda, B., and Tesh, V. L. (1996). Differentiation-associated toxin receptor modulation, cytokine production, and sensitivity to Shiga-like toxins in human monocytes and monocytic cell lines. Infect. Immun. 64, 1173-1180.

Ramos, M. V., Fernandez, G. C., Patey, N., Schierloh, P., Exeni, R., Grimoldi, I., et al. (2007). Involvement of the fractalkine pathway in the pathogenesis of childhood hemolytic uremic syndrome. Blood 109, 2438-2445. doi: 10.1182/blood-2006-06-026997

Roberts, T. J., Sriram, V., Spence, P. M., Gui, M., Hayakawa, K., Bacik, I., et al. (2002). Recycling CD1d1 molecules present endogenous antigens processed in an endocytic compartment to NKT cells. J. Immunol. 168, 5409-5414. doi: 10.4049/jimmunol.168.11.5409

Robson, W. L., Leung, A. K., Trevenen, C. L., and Brant, R. (1993). Diarrheaassociated hemolytic uremic syndrome. Can. Fam. Physician 39, 2139-2145.

Roche, J. K., Keepers, T. R., Gross, L. K., Seaner, R. M., and Obrig, T. G. (2007). CXCL1/KC and CXCL2/MIP-2 are critical effectors and potential targets for therapy of Escherichia coli O157:H7-associated renal inflammation. Am. J. Pathol. 170, 526-537. doi: 10.2353/ajpath.2007.060366

Ryan, C. A., Tauxe, R. V., Hosek, G. W., Wells, J. G., Stoesz, P. A., Mcfadden, H. W. Jr., et al. (1986). Escherichia coli O157:H7 diarrhea in a nursing home: clinical, epidemiological, and pathological findings. J. Infect. Dis. 154, 631-638. doi: 10.1093/infdis/154.4.631

Sauter, K. A., Melton-Celsa, A. R., Larkin, K., Troxell, M. L., O’brien, A. D., and Magun, B. E. (2008). Mouse model of hemolytic-uremic syndrome caused by endotoxin-free Shiga toxin 2 (Stx2) and protection from lethal outcome by anti-Stx2 antibody. Infect. Immun. 76, 4469-4478. doi: 10.1128/IAI. 00592-08

Sekine, M., Monkawa, T., Morizane, R., Matsuoka, K., Taya, C., Akita, Y., et al. (2012). Selective depletion of mouse kidney proximal straight tubule cells causes acute kidney injury. Transgenic Res. 21, 51-62. doi: 10.1007/s11248-0119504-z

Shimizu, M., Kuroda, M., Sakashita, N., Konishi, M., Kaneda, H., Igarashi, N. et al. (2012). Cytokine profiles of patients with enterohemorrhagic Escherichia coli O111-induced hemolytic-uremic syndrome. Cytokine 60, 694-700. doi: 10.1016/j.cyto.2012.07.038

Shiraishi, M., Ichiyama, T., Matsushige, T., Iwaki, T., Iyoda, K., Fukuda, K., et al. (2008). Soluble tumor necrosis factor receptor 1 and tissue inhibitor of metalloproteinase-1 in hemolytic uremic syndrome with encephalopathy. J. Neuroimmunol. 196, 147-152. doi: 10.1016/j.jneuroim.2008.02.012

Smyth, J. W., and Shaw, R. M. (2008). Visualizing ion channel dynamics at the plasma membrane. Heart Rhythm 5, S7-S11. doi: 10.1016/j.hrthm.2008.02.015

Stearns-Kurosawa, D. J., Collins, V., Freeman, S., Tesh, V. L., and Kurosawa, S. (2010). Distinct physiologic and inflammatory responses elicited in baboons after challenge with Shiga toxin type 1 or 2 from enterohemorrhagic Escherichia coli. Infect. Immun. 78, 2497-2504. doi: 10.1128/IAI.01435-09

Stearns-Kurosawa, D. J., Oh, S. Y., Cherla, R. P., Lee, M. S., Tesh, V. L., Papin, J., et al. (2013). Distinct renal pathology and a chemotactic phenotype after enterohemorrhagic Escherichia coli shiga toxins in non-human primate models of hemolytic uremic syndrome. Am. J. Pathol. 182, 1227-1238. doi 10.1016/j.ajpath.2012.12.026

Stone, S. M., Thorpe, C. M., Ahluwalia, A., Rogers, A. B., Obata, F., Vozenilek, A., et al. (2012). Shiga toxin 2-induced intestinal pathology in infant rabbits is A-subunit dependent and responsive to the tyrosine kinase and potential ZAK inhibitor imatinib. Front. Cell. Infect. Microbiol. 2:135. doi: 10.3389/fcimb.2012.00135

Su, C., and Brandt, L. J. (1995). Escherichia coli O157:H7 infection in humans. Ann. Intern. Med. 123, 698-714. doi: 10.7326/0003-4819-123-9-19951101000009

Valles Pg, M. S., Gonzalez, A., Manucha, W., Bocanegra, V., and Valles, R. (2012). Toll-like receptor 4 expression on circulating leucocytes in hemolytic uremic syndrome. Pediatr. Nephrol. 27, 407-415. doi: 10.1007/s00467-011-2014-7

Webb, T. J., Giuntoli, R. L. II., Rogers, O., Schneck, J., and Oelke, M. (2008). Ascites specific inhibition of CD1d-mediated activation of natural killer T cells. Clin. Cancer Res. 14, 7652-7658. doi: 10.1158/1078-0432.CCR-08-1468

Webb, T. J., Litavecz, R. A., Khan, M. A., Du, W., Gervay-Hague, J., Renukaradhya, G. J., et al. (2006). Inhibition of CD1d1-mediated antigen presentation by the vaccinia virus B1R and H5R molecules. Eur. J. Immunol. 36, 2595-2600. doi 10.1002/eji.200636024

Zanchi, C., Zoja, C., Morigi, M., Valsecchi, F., Liu, X. Y., Rottoli, D., et al. (2008). Fractalkine and CX3CR1 mediate leukocyte capture by endothelium in response to Shiga toxin. J. Immunol. 181, 1460-1469. doi: 10.4049/jimmunol.181.2.1460

Conflict of Interest Statement: The authors declare that the research was conducted in the absence of any commercial or financial relationships that could be construed as a potential conflict of interest.

Copyright (c) 2015 Obata, Subrahmanyam, Vozenilek, Hippler, Jeffers, Tongsuk, Tiper, Saha, Jandhyala, Kolling, Latinovic and Webb. This is an open-access article distributed under the terms of the Creative Commons Attribution License (CC $B Y)$. The use, distribution or reproduction in other forums is permitted, provided the original author(s) or licensor are credited and that the original publication in this journal is cited, in accordance with accepted academic practice. No use, distribution or reproduction is permitted which does not comply with these terms. 